\title{
RESEARCH
}

\section{A DISCURSIVE CONSTRUCTION OF IDENTITIES THROUGH VERBAL HUMOR}

\author{
Nguyen $\mathrm{Hoa}^{*}$ \\ VNU University of Languages and International Studies, \\ Pham Van Dong, Cau Giay, Hanoi, Vietnam
}

Received 10 April 2017

Revised 08 May 2017; Accepted 15 May 2017

\begin{abstract}
This study focuses on how verbal humor can discursively construct identities, grounded in the assumption of social constructionism that identity is not given, but is constructed in social practice (Foucault, 1984), or discourse practices (Fairclough, 2001). I exploit a mix of Critical Discourse Analysis (CDA) methods and Gricean pragmatics in the analysis of implicature-generated humor occurring in a speech delivered in the political context of a presidential election. The findings show that verbal humor (created through the use of language in contexts of situation) is not just for "fun" or "humor", but also for performing a variety of pragmatic functions such as developing social relations, creating solidarity, or the construction of identities in socio-political contexts (presidential election), which is consistent with other research projects concerning the function of verbal humor.
\end{abstract}

I have made every effort to conceal the identity of the individuals to the possible extent in ways that do not hinder comprehension. The two main characters are named John and Mary. Three individual are coded $\mathrm{X}, \mathrm{Y}$, and $\mathrm{Z}$ as they appear in the remarks. The election happened in country A.

Keywords: identity, image, humor, construct, discursive, intertextuality, interdiscursivity

\section{Introduction}

Identity has received much attention from many disciplines including psychology, social and cultural anthropology, philosophy, art, and linguistics. For some, identity is identification with something. For others, it may be seen as a label that distinguishes one individual or group from another. So far, research interests have been devoted to how language is constitutive of identity. This study focuses on the function of humor in forming and shaping identities that we as human beings acquire. Humor

* Tel.: 84-912311569

Email: hoadoe@yahoo.com / nguyenhoa@vnu.edu.vn research is not just focused on the dimension of "fun" or the "humorous effects", but also on the pragmatic aspects of humor. But a point worthy of note is that to date little research has been carried out to explore how verbal humor can discursively construct identities in socio-political context. Most of the work done so far indicates that humor can perform a variety of functions such as maintenance of good relations with fellow workers (Holmes, 2006), creating solidarity, power or dealing with a psychological problem (Hay, 2000). Habib's study (2008) applying ethnography of communication approach explained how disagreement and teasing (humor) can work 
together to enrich pragmatic and cultural knowledge and display personal identity in cross-cultural communication.

This study takes a discursive approach to identity construction, looking at how verbal humor can discursively construct identities, and what discursive resources are exploited to achieve this goal. I want to stress the fact that this study is concerned with identity construction in a socio-political context. The notion of humor is often defined in terms of irony and sarcasm, and this study just uses the term "humor" regardless of whether the intended effect is ironic or sarcastic.

\section{The context}

The setting is a presidential election in country A. This election is believed to be unprecedented in many ways. For the first time in its history, a woman has been nominated by a major party to carry its mantle. Further, the two candidates had high negatives. For example, an article in a famous journal reported that "some $60 \%$ of registered voters held a negative view of John, ..." and "Mary fared somewhat better, with $55 \%$ viewing her in a negative light...". Opinions were expressed in the media in such terms as "crazy", "unpredictable" or "taking a dark turn", or "race to the bottom". John and Mary were both trying to construct the other's identities in such unheard-of terms as: "crooked", "lying", "mentally unfit", "dangerous", or "unfit to be president". A CDA of the speech in such context can be ideologically, socially, or linguistically revealing. Mary has made many speeches on the campaign trail, but I find the speech given at the event in question of special linguistic significance as it includes self-deprecating humor while roasting the other candidate.

The event, where the Mary's remarks were given, is an dinner for the elite politicians, media figures, and clergyman who gather for fun and for raising money for the disadvantaged children in the name of Catholic charity. The interesting thing about this gathering is every four years, two presidential candidates are on hand to traditionally roast each other with gentle jabs and make self-deprecating jokes.

\section{Theoretical and analytical framework}

This study draws on critical discourse analysis (CDA) which has its impact felt in many disciplines in the social sciences and humanities. As Jorgensen and Phillips (2002) note CDA is more concerned with the linguistic organization of discourse (text and talk). As talk and text are oriented toward social action, it follows that their meaning is dependent on context or the use to which language is put, or we may say that this language use is context-bound. But it is crucial to keep in mind that language use in social contexts is viewed as resources for use by people to construct the world, social relations and identities. This view is shared by researchers in anthropology, linguistics, psychology, sociology, history, literature, gender studies, and social theories, among others, (Fina, Schiffrin, \& Bamberg, 2006).

Firmly grounded in social constructionism, CDA studies how people use discursive resources to construct their social world and perceptual realities. CDA views identity as something not isolated, not autonomous, but rather as a something that is formed, negotiated and shaped or reshaped in discourse. Seeing identity as constructed implies a reorientation from a more essentialist position. Some philosophers of anti-essentialist orientation like Rorty (1980) argues that identity is a culturally specific discursive construction. In other words, we no longer view a person as having an identity, but rather we focus on the discursive process in which his or her identity is made, changed, negotiated, or maintained. 
Language does not reflect the world out there, but is better understood as repertoires at our disposal to "make" or to "construct" the social world. A person's identity whether it be social, personal, or professional, is something that is not reflected, but constructed, negotiated in discourse; and language offers choices to do this job, (Potter and Whetherell, 1987). Choosing the right discursive resources will enable a speaker/writer to achieve his or her goal of identity construction.

The idea that language at best only represents or reflects reality stems from the view that reality is external to, and independent of, how we as human beings makes sense of, and conceptualize, or "construct" the world. Lakoff and Johnson (1980/2003: 146) rightly observe that such a view does not take into account "the human aspects of reality, in particular the real perceptions. Conceptualizations, motivations, and actions that "constitute" most of what we experience". In the same vein, Jorgensen and Phillips (2002/2014) believe that rather than just neutrally reflect the world, identities, and social relations, discourse plays an active role in creating and changing them. But I will see a dialectical relationship between representation and construction: we represent the world by constructing it, and we construct the world by representing it. Representing the world in one way or another is something we all do in the production of discourse and construction of the world. We use language to both represent our identity and at the same time construct it. "Construction" is used in this sense in this study.

I will now just discuss Norman Fairclough's discourse analytical framework, which I will apply in my analysis. Fairclough regards discourse as a social practice, or a kind of language used in a particular domain, and/ or as a way of speaking that gives meaning to experiences from a particular perspective.
Discourse, in his view, constructs identities, social relations and systems of knowledge and meaning. Foucauldian discourse analysis takes a similar view. There are obvious reasons to choose this framework. First, as Jorgensen and Phillips observe this framework is a textoriented form of discourse analysis where the use of language figures prominently. Second, Fairclough also believes that the analyst needs to go further than just focusing on a detailed textual analysis, and his job is to explain the links between texts and societal and cultural processes and structures. One of Fairclough's major contributions is his understanding of discourse as both constitutive and constituted in the sense that it both constitutes the social world and is constituted by other social practices.

Fairclough views each instance of language use as a communicative event, which can be an article, a political speech, or interview, and in this case it is the remarks made by Mary at the Alfred E. Smith Dinner. This can be seen as made up of three aspects: the text, the discursive practice, and the social practice. Fairclough's approach will entail analyzing the use of linguistic resources such as vocabulary, syntax and textual organization from which discourses and genres are realized linguistically, and analysis of discursive practice, which is about how existing discourses and genres are drawn upon to produce and consume (interpret) a text or talk. The role of the (inter) discursive practice is to mediate the relationships between texts and social practice. In other words, it is about the strategies used. The social dimension provides the content aspect, but understanding it will require knowledge of socio-cultural, and political theories. In short, CDA's aim is to provide an account of the linguistic-discursive dimension of the social (Fairclough and Wodak, 1977). The following figure represents the model used in this study. I have made a small change from "discursive" into 
"interdiscursive" as interdiscursive practice is the rule rather than the exception.

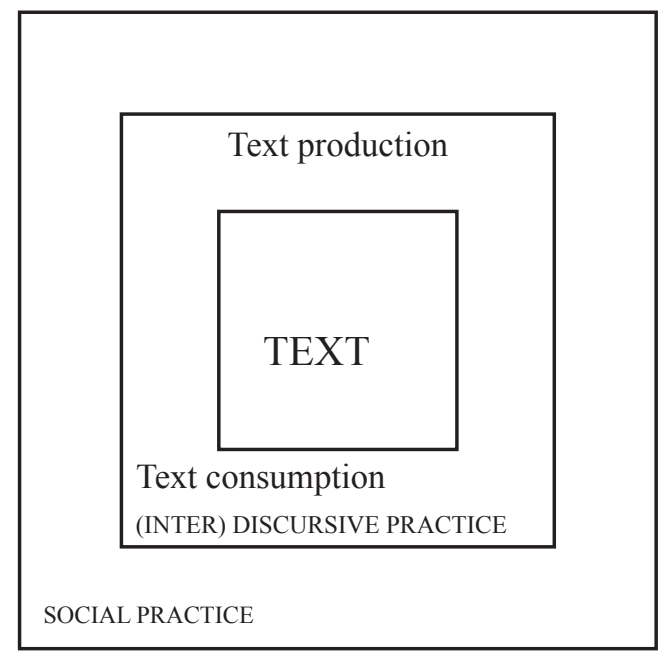

Fairclough's adapted three-dimensional model for Critical Discourse Analysis (1992a: 73)

\section{Some key notions}

In what follows, I will try to clarify some of the key terms underpinning this study. First is the notion of "identity", which is closely linked to that of "Image", which has been the subject matter of many disciplines especially art, literature, cognitive linguistics. Generally, image is viewed as a visual perception, or a mental picture of an entity. As such, it is a make-up of the major traits or defining characteristics of an entity, or in other words, of identities. Identity is a historical, social and cultural construct, and as such it is not neutral as it tells us about who we are in terms of our gender, social class, age, sexual orientation, race and ethnicity our power, ideologies, and value systems from a certain point of view. Similarly, in terms of identity theory the core of identity is the categorization of the self as an occupation of a role, and the assignment of meanings, expectations, and its performance to that role (Burke and Tully, 1977; Stets and Burke, 2000). For example, a person can be said to possess a numbers of identities as a "politician", a "university lecturer" a "neighbor", or a "community organizer". In this study, "identity" will be used in the latter sense to denote a particular instantiation or manifestation of the image associated with an individual. The construction of identity spells out what it equals and what it differs from. Identity construction can happen in a myriad of ways, for example in art by way of metaphor or symbolic communication (Dowling, 2011), or in discourse, which is the issue this study deals with. Discursive psychologists such as Potter and Whetherell, and critical discourse analysts (Fairclough) see identity as a discursive construct. That is something we use language to create in socially-situated interaction. Note that the term "identity" is used in two ways either as a non-count or a count noun. In the former instance, it is the overall image of an individual whereas in the latter case, it refers to each manifestation of a person in a particular context.

The other notions are "intertextuality" and "interdiscursivity". "Intertextuality" was first coined by Kristeva (in "The Kristeva Reader", edited by T. Moi, 1966) as an attempt to combine Saussure's semiotics with Bakhtin's dialogism. For Kristeva, meaning is not transferred directly from writer to reader but is mediated through or filtered by, codes imparted to the reader by other texts. For Jorgensen and Phillips (2002), intertextuality refers to the conditions where all communicative events draw on earlier events, and the language that have been used before are used. This means that texts draw on other texts (Fairclough, 1992), for example, by citing them. One example is the use of reported speech. Reisigle and Wodak posit that texts are linked to other texts in a phenomenon called "intertextuality" through reference to a topic or events by allusions or evocation; or by the transfer of the main arguments from one text to the next. The process of transferring is 
referred to as "recontextualization". The most obvious example of intertextuality is reported speech or quotes.

Interdiscursivity, on the other hand, may be seen as a mix of discourses, genres and styles in a communicative event, or a single text, and it is a form of intertextuality. In simple terms, it is the creation of a text's meaning by other texts. Among the means available, quotation and allusion are most common. It is rare to find a "pure" discourse or text in practice. About the distinction between intertextuality and interdiscursivity, the following can be said: Intertextuality refers to texts which are made up of elements from other texts (quotes, for example), whereas interdiscursivity is about the process of constituting texts by combining discourses, genres and styles from the language system, or in other words, simply making linguistic choices to achieve strategic purposes.

Allusion is defined by the Longman Dictionary of Contemporary English (1987) as an act of speaking about something or somebody in an indirect way. Another way of looking at it is as a passing or casual reference, an incidental mention of something, either directly or by implication. It is often confused with intertextuality.

\section{The framework of textual analysis}

It is quite hard to find a well-defined empirical methodology in CDA, and its landscape seems to be that of a number of approaches characterized by theoretical similarities (Wodak and Meyer, 2009), and eclecticism. Our review reveals that there are two main approaches to textual analysis. One approach is offered by Machin. D and Mayr (2012), which is not limited to word choices, but actually goes further into more dynamic dimensions of the interaction including intertextuality, personalization, individualization and collectivization, nomination or functionalization, representing action, concealing and taking for granted, persuading with abstraction, committing to, and evading truth. Fairclough (2001), based on systemic functional grammar, proposes a list of guiding questions, looking at the use of vocabulary in terms of their experiential, expressive, relational values that words have, and metaphors, especially conceptual metaphors. Grammar is also analyzed along similar lines. Textual structures, are analyzed, as well.

I adopt a mix of Fairclough's analytical model and the pragmatic approach in this study of humor-constructed identity. I will, while keeping the two phases of interpretation and explanation, not apply Fairclough's first phase of textual description. Instead, I will basically takes the Gricean pragmatic approach to the textual analysis of the realization of creating identity, based on humor as it serves its socio-pragmatic function in self or otherconstruction. Humor hails from implicature, which is engendered by flouting one or more of the CP maxims (Leech, 1983). Flouting may be defined as an act of breaking a maxim on purpose to create implicature, and in this sense it is conversationally cooperative. Thus, the analytic approach involves finding out 1) what maxim(s) is flouted, 2) what knowledge is presupposed, and 3) what interdiscursive strategy is employed either to enable a speaker to appear objective, or to shield the speaker from committing to a fact.

Implicature refers to what a speaker can imply, suggest, or mean, as distinct from what he literally says. Here is what Grice (1975: 49/50) says about implicature:

"A man who, by (in and when) saying (or making as if to say) that p has implicated q, may be said to have conversationally implicated that q, PROVIDED THAT (1) he is presumed to be observing the conversational maxims, 
or at least the Cooperative Principle; (2) the supposition that he is aware that, or thinks that, $q$ is required in order to make his saying or making as if to say $p$, (or doing so in THOSE terms) consistent with this presumption; and (3) the speaker thinks (and would expect the hearer to think that the speaker thinks) that it is within the competence of the hearer to work out, or grasp intuitively, that the supposition mentioned in (2) is required".

To work out implicature, Grice suggests that the hearer needs to know or share the conventional meaning of the utterance, the $\mathrm{CP}$ maxims, the context of the utterance, background knowledge, and the fact that all relevant elements mentioned above are available to both participants, and they know or assume this to be the case (Grice, 1975). It is apparent that both linguistic knowledge, and sharing background knowledge or information seem to be crucial in making sense of implicature upon which humor is based. There is no doubt that implicature is one of the key factors that creates humor, and shared background knowledge operates as the basis for interpreting and grasping the intended meaning or the illocutionary force of the punch utterance through the act of alluding. Cutting (2015) offers a brief description of how maxims can be flouted. In particular, he discusses in greater detail the flouting of the quality maxim. According to Cutting, this maxim can be flouted by using an exaggeration (or hyperbole), or a metaphor, or an irony and banter, or sarcasm. As Attardo (1994) observes all jokes involve the flouting of at least one maxim, and in many cases of all maxims.

Without a shared background or contextual knowledge, it is impossible for jokes to go off as intended. A viewing of the video shows that those present there enjoyed themselves and laughter could be heard at the end of each joke. But, a group of Vietnamese MA students whose major is English were shown this video, and it is apparent that they simply watched it with some interest, but they did not show any obvious appreciation of the humor. They simply did not laugh.

\section{Construction of identities by humor: findings and discussion}

Mary's speech at the Dinner in question is the empirical material for my analysis (for the transcripts, see References). Her speech consists of 13 punchline jokes made about John as identified by me, and the structure of punchline joke includes a setup which is the narrative providing background information, and the punchline or the laugh line. It is simply referred to as a joke. In this study, I will only focus on the jokes about John, not the selfdeprecating ones that Mary made about herself. My analysis of the data will focus on maxim flouting, the kind of assumed knowledge, and the interdiscursive strategy involved. In addition, to find out the social dimension of the speech, content analysis was used to set up a conceptual framework within which to conduct this study, as suggested by Baker \& Galasinski (2001). This framework can offer key information on the main themes contained therein. These themes were cross-checked with those found in other speeches that these two individuals made on their campaign trails, and in using this method, I am fully aware of its limitations as content analysis may not be able to reveal the underlying motives, and be limited by availability of materials (in this case, just the above mentioned text). The main themes serve as the grounds for sketching the image of the individual (John). Our findings are presented below.

1. John is a sexist.

Example 1. "But this has been a really strange campaign. You saw it last night 
and tonight. John has attacked me for life in public service. I did not get that at first. I kind of get it now. As he told X, he does not like it when women have been around for more than 35 years".

Example 2. "People look at the Statue of Liberty and they see a proud symbol of our history as a nation of immigrants, a beacon of hope for people around the world. John looks at the Statue of Liberty and sees a "four." (LAUGHTER) "Maybe a "five" if she loses the torch and tablet and changes her hair". (LAUGHTER)

As is discussed above, a very critical part of the joke is the narrative or the act of narrating performed by the joke creator. This part that provides a lead-in to the punchline where the implicature is to be found. It may not matter whether this narrative is true or not. These jokes are based on a presupposition of socio-cultural background knowledge: It is no secret that in a radio talk, John described a woman sexually at her best at thirty, and he checked out of the relationship at thirty five. As owner of the Miss World beauty pageant, John is known to rate a woman's body from one to ten. This is the knowledge that Mary assumed people present there had.

The punchline is: “...sees a 4. Maybe a 5 ", which reminds the audience of what they know about John's habit of rating a woman's body from one to ten. Obviously, alluding is the speech act that is performed by the speaker and pervades implicature-induced humor.

The interdiscursive strategy here is the use of reported speech to allude to the assumed knowledge: "As he told X, he does not like it when women have been around for more than 35 years".

Flouting of the quality maxim occurs here by way of using a sarcasm: John looks at the Statue of Liberty and sees a 4. Maybe a 5 if she loses the torch and tablet and changes her hair".

\section{John is a racist.}

Example 3. "And if John does win, it will be awkward at the annual President's Day photo, when all the former presidents gather at the White House, and not just with Bill. How is Barack going to get past the Muslim ban?" (LAUGHTER)

Mary presupposed that the audience had access to, or shared the background knowledge of what happened on the campaign trail. John is known to say that he would impose a total ban on Muslim immigration into the country, though he flip-flopped on occasions. Mary simply alluded to this fact.

Flouting the maxim of quality: It is not at all clear whether what Mary talks about will happen. That is Barack is not going to be there. The key is the use of "awkward" as a metaphor.

3. John seemingly had a personality and temperament problem.

Example 4. "And, you know, because this is a friendly dinner for such a great cause; John, if at any time, you don't like what I'm saying feel free to stand up and shout "Wrong!" while I'm talking”. (LAUGHTER)

Presupposition of socio-cultural background knowledge: John is seen in debates to make a lot of interruptions when Mary is speaking. This is a violation of the rules they agreed upon. They both have a time limit for their turns. He looks rude in the debates.

Intertextuality is an obvious feature of this joke as Mary was trying to allude to what actually happened at the debates: and shout "Wrong" while I'm talking". Mary flouts the maxim of quality (And because this dinner is for such a great cause, John, if at any time you don't like what I'm saying).

He is ready to say anything without any evidence. For example, he can make a false claim that Mary used drug to be able to 
get through the tough going debates. As is apparent from example 5 .

Example 5. "There is nothing like sharing a stage with John. John wanted me drug tested before last night's debate. And look, I've got to tell you, I am so flattered that John thought I used some sort of performance enhancer." (LAUGHTER). "Now, actually, I did. It's called preparation". (LAUGHTER)

Presupposition of socio-cultural background knowledge: John was reported to be ready to say anything unhinged. Then he denied ever saying it. For example, he said that he did not supported the War in Iraq, but this claim was fact-checked, and it turned out that he actually supported it. Mary smartly used this to evoke the sense that John was not prepared for the job he wanted.

Mary on purpose flouted the maxim of quality when saying: "I am so flattered that John thinks I used some sort of performance enhancer". And intertextuality is manifested when she reported: "John wanted me drugtested before last night's debate.". This was a ridiculous charge against Mary.

Another example is example 6 where John is a portrayed as a "sore loser". "You know, I've had the privilege of being at the Al Smith dinners in years past and I always enjoy it. But, remember, if you're not happy with the way it comes out, it must be rigged." (LAUGHTER)

Presuppositionofsocio-culturalbackground knowledge: John constantly complained that the system was rigged against him, everything, even the polls. The conventional wisdom is that people whine when they are losing. John's character was put on the line, evoking a sense of untrustworthiness.

4. John was constructed as unprepared for the job.

Example 7. "And I don't understand their unhappiness. They say John doesn't have any polit-cies (sic). He has no policies. I keep hearing that. I'd actually like to defend him on this. John has issues, serious issues." (LAUGHTER). "Really, really serious issues". (LAUGHTER). "And I worry about John's go it alone attitude. For example, at his convention, when he said I alone can fix it, you know, in the '90s, I said the same thing about America's health care system and it didn't work out so well for me, either."

Presupposition of socio-cultural background knowledge: At the National Convention, John declared: "I alone can fix it". Here the strategy is the use of intertextuality: "he said: I alone can fix it.". By alluding to this act by John, Mary was smart enough to remind the audience that this attitude will inevitably fail as was the case with her in the early 1990s when she was leading the efforts at health care. Again the maxim of quality is flouted as Mary said she was "defending him". It was simply not true.

Mary employed an interdiscursive strategy to achieve this goal "They say John doesn't have any polit-cies (sic)”.

5. John may have a problem with trust. This is shown by the fact that John has dubious business practice, as is illustrated by the following example.

Example 8. "Now, look, I have deep respect for people like Y. She's working day and night for John and because she's a contractor, he's probably not even going to pay her." (LAUGHTER) (BOOS)

What was presupposed was the fact that there are stories in the media that John refused to pay his contractors for the work they did for him. Mary obviously alluded to this fact, reminding people that John was not trustworthy as he did not honor the promise to pay when the work was finished.

The punchline is: "she is a contractor, he is probably not even going to pay her." 
This implicature is created by the flouting of the maxim of relation. One has to be able to understand the link between having deep respect for $\mathrm{Y}$ and the fact that John was probably not going pay her for the work she was doing for him.

Example 9. "For example, I have tried to inspire young people by showing them that with resilience and hard work, anything is possible, and you are doing the same. A thirdgrade teacher told me that one of her students refused to turn in his homework because it was "under audit."

Presupposition of socio-cultural background knowledge: John has consistently refused to release his tax returns, which is a common practice in the country when someone is running for the highest office of the land. The implication here is that he had something fishy to hide, and it is also noteworthy that intertextuality occurs here, too (A third-grade teacher told me ...).

Mary flouted the maxim of quality too: "A third-grade teacher told me that one of her students refused to turn in his homework because it was "under audit". In fact no teacher had ever told her. It was simply made up. Flouting of relation occurred as the audience was expected to be able to imagine what was not said, and make the connection between the first and second utterance of this joke.

Example 10. "Republicans in particular seemed frustrated with their nominee. The Speaker told the members of the House, "You don't have to support the top of the ticket; just do what's in your best interest." So I guess John really has unified his party around his core philosophy".

As news of John's own stories about his sexual behavior emerged, The House Speaker was known to tell their members everyone for himself. This was what Mary presupposed to happen. This, according to Mary, applies to John and is attached to him as a defining trait or core philosophy. He looked after only himself. The key to humor is intertextuality in the form of reported speech is used here to allude to what the Speaker said: the Speaker told the members of the House.... In reporting the House Speaker's words, Mary did not commit herself to this reality. Flouting the maxim of quality was the case, too: So I guess John really has unified his party around his core philosophy".

6. John is influenced by a foreign actor.

Example 11. "Now, you notice there is no teleprompter here tonight, which is probably smart, because maybe you saw John dismantle his prompter the other day. And I get that. They're hard to keep up with, and I'm sure it's even harder when you're translating from the original Russian”. (LAUGHTER)

Presupposition of background knowledge: John was reported to dismantle the teleprompter when it did not work. It is obvious that Mary flouted the maxim of quality. There is no evidence that: "... when you are translating from the original Russian", and the maxim of relation as well. The hearers are expected to be able to imagine what is not said there, but make the connection between dismantling the teleprompter and translating from the Russians. In other words, Mary wanted to imply that John was speaking the language of the Russians. Now we know that in January, 2017, a newspaper ran this headline "Declassified report says President $\mathrm{Z}$ 'ordered' effort to undermine faith in our election and help John", reporting this as the conclusion of multiple intelligence agencies.

Example 12. "But I - but I kind of want to just put the information out there, so everybody can draw their own conclusions and you can judge our relative health. We've each released our medical records. My blood pressure is 100/70. His is unbelievably great." 
(LAUGHTER). "My cholesterol is 189, his is presidential". (LAUGHTER)

"My heart rate is 72 beats per minute, his is the most beats ever, or the least beats ever, whichever sounds best." (LAUGHTER). "But John really is as healthy as a horse, you know, the one President $Z$ rides around on." (LAUGHTER)

Presupposition of socio-cultural background knowledge: John was said to be an admirer of a foreign leader, who is regarded as a dictator, and not a friend of America, he went so far as to say that the current president of the country was a weaker president than him. He seemed to subscribe to many of the political lines held by the Russians. It was very strange when his doctor released his statement of health in terms believed to be very unprofessional. Here in this joke, intertextuality abounds in this humor: My blood pressure is 100/70. His is unbelievably great. My cholesterol is 189. His is "presidential." My heart rate is 72 beats per minute. Flouting the maxim of quality using a sarcasm (...the one that President $Z$ rides around on) and hyperbole (as healthy as a horse) are crucial.

7. John might be seen as behaving in a way not acceptable in a democracy.

Example 13. "You know, come to think of it, it's amazing I'm up here after John. I didn't think he'd be okay with a peaceful transition of power". (LAUGHTER) (APPLAUSE)

Presupposition of socio-cultural background knowledge: Mary alluded to what John said during the third debate: when asked whether he would accept the results of the election, he said; "I'll keep you in suspense", refusing to say in the affirmative that he would honor American tradition of democracy. In the minds of many, this act might pose as a threat to democracy. Here, the maxim of quality was flouted as it was not true that John would be okay with a peaceful transition power. Mary actually used something which may be described as both an example of sarcasm and exaggeration (It's amazing!).

My analysis of these instances of humor in Mary's speech shows how humor plays a powerful role in the production of identity of John. Mary as the speaking subject chose discursive devices from existing repertoires that lean toward a world-to-person direction of the fit. Mary was trying to narrate a world to fit John by way of implication. The themes identified above look like a series of descriptions of an individual in language, but they implicitly construct John's image as a sexist and racist, a person unqualified to be president and commander-in-chief. That is the key message that Mary tried to hammer in her speech and throughout the campaign and probably with some success with the audience as they laughed (and probably with certain blocks of voters as she won more popular votes).

The underlying basis is the production of implicature by Mary, followed by a successful interpretation of it by the hearer (audience). For this purpose, Mary consistently flouted the Gricean maxims. All this happened in a social context (the Foundation Dinner), based on a presupposition of some facts, stories, or incidents, or simply background knowledge, supposedly available and known to the audience. To allude to that supposedly shared knowledge, intertextuality is the main resource. It is not clear to me how Mary chose all the stories and incidents to presuppose. Some of them go back a long way, to the radio talk with X, for example. But it can be said that the selection of the incidents was wise. It was a clever choice to serve her purpose. By hammering on the themes of sexism and racism, she was, in my view, trying to appeal to women, and especially the non-EuropeanAmericans, the increasingly important constituencies in the election. All the incidents 
about his character should be what she had in mind. At the end of the day, a question often asked by the voters is do I trust this person to run the country. The act of narrating takes on a crucial role as it lays the groundwork leading up to the punchline or laugh line. Implicature underpins the humor, but it is apparent that both background knowledge and its presupposition play a critical role as the basis of humor. However, it should be stressed that all these discursive strategies (presupposition of background knowledge, interdiscursive practice, and narrating to lay the groundwork for the humor) work together in tandem as a function of factors. The smart choice of discursive tools by Mary provides consistent proof that discourse can be viewed as a system of options, and that the construction of identity or the social realities is selective. Our intertextual analysis shows the journey of text-embedded ideas from one site (a story told by a person) to another (it got reported/ narrated as part of the joke). However, what emerges out of the analysis is that the key role of a negative construction of John's identities was accorded to humor created by the act of presupposing. It worked as the audience understood the humor and they laughed as they worked out the implicature, based on their shared linguistic and background knowledge, as Grice mentioned. Mary was implicitly constructing John's identities by creating humor, which involves using the strategy of flouting the Gricean maxims based on presupposition. The strategy was made possible because she assumed that that stories she was narrating were what everybody knew and not that she was painting his image as such. She wanted to make it real.

\section{Conclusion}

This study has adopted the discursive approach of identity construction, but shifted from the common practice of textual description (Fairclough, 2001b) to an analysis of implicature-based verbal humor. Our findings are consistent with other researches in that verbal humor can function pragmatically. It plays an effective role in constructing the image and identities that we want to make of others. The themes identified above in negative terms construct John's image as someone with racist and sexist ideas, and not qualified to be president and commander-in-chief. This is the identity of a role and the assignment of meanings, expectations, and its performance associated with that role. This is what negative otherconstruction is all about. A successful construction and interpretation of the humorinduced identity is evidenced in the video by the audiences' laughter, groans and boos. That image is constituted of the identities that have been figured out above. This study indicates that CDA is interdisciplinary by nature, and thus, a mix of approaches and methods is the appropriate choice, and should be adopted if we want to know what identities are, how they are created, changed, or reproduced. The discursive strategies that are used here include flouting the CP maxims based on presupposition of socio-cultural background knowledge, intertextuality, and narrating what is assumed to be known and available to the audience (the setup to the punchline). The act of alluding is not realized linguistically, but is inferred. The interpretation of identities contains an element of subjectivity as the audience is engaged in a sense-making process. The issue is how real that identity is, or is it just a intended construct? I will argue that it was more or less appreciated as real because it produced effects (laughter by the audience). A negative picture was painted of John using the above resources, and the question is whether a positive image can be made using 
the same. I think the answer is yes because it is the choice of these discursive strategies that makes the difference. It is obvious that the perceived implicature triggers the shift, but how it works remains an issue to deal with. Also, it remains to explore and understand how cultural values (for example, constructs of individualism and collectivism (Triandis, 1995) linked to personality traits, behavior, and habits may actually play out in both the construction and interpretation of identity. Verbal humor is an effective tool to construct identities and create image.

\section{References}

Agger, B. (2013). Critical social theories (3 $3^{\text {rd }}$ ed.). New York: OUP.

Attardo, S. (1993). Violation of conversational maxims and cooperation: the case of jokes. Journal of Pragmatics, Vol 19(6), 537-558.

Attardo, S. (1994). Linguistic theories of humor. Berlin, New York: Mouton de Gruyter.

Attardo, S. (2003). The Pragmatics of Humor. Journal of Pragmatics. Vol 35(9), 1287-1449.

Attardo, S. (2008). Semantics and Pragmatics of Humor. Language and Linguistics Compass, Vol 2(6), 1203-1215.

Baker, C \& D. Galasinski. (2001). Cultural studies and discourse analysis: A dialogue on language and identity. LA, London, New Delhi, and Singapore: Sage Publications.

Brown, P \& Levinson, S. C. (1987). Politeness: some universals in language usage. Cambridge, New York, Port Chester, Melbourne, and Sydney: CUP.

Berger, P. \& T. Luckman. (1967). The social construction of reality. Harmondsworth: Penguin.

Calhoun, C. (1995). Critical social theory. Oxford, UK: Blackwell Publishing.

Dornyei, Z \& Ushioda, E (Eds) (2009). Motivation, Language identity and the L2 self. Bristol, Buffalo, and Toronto: Multilingual Matters.

Dowling, S. J. (2011). Constructing identity:identity construction. Unpublished MA thesis. Georgia State University. Retrieved December $15^{\text {th }}$ 2015, from http://scholarworks.gsu.edu/.

Fairclough, N. (1992). Discourse and social change. London: Longman.

Fairclough, N. (2001). Language and power. Malaysia: Pearson Education Limited.
Fairclough, N \& Wodak, R. (1977). Critical discourse analysis, in T. van Dijk (ed.), Discourse as social interaction: Discourse studies: A multidisciplinary introduction. Vol. 2. London: Sage.

Fina, A. D, Schiffrin, D, \& Bamberg, M. (2006). Discourse and identity. UK: CUP.

Foucault, M. (1969). The archeology of knowledge. London: Tavistock.

Foucault, M. (1984). The history of sexuality. Harmondsworth: Penguin.

Grice, H.P. (1975). Logic and conversation in (eds.) P. Cole \& Morgan, J. Syntax and semantics 3: Speech acts. New York: Academic Press.

Gumperz, J. J. (1982). Language and social identity. Cambridge, New York, New Rochelle, Melbourne, Sydney: CUP.

Halliday, M.A.K \& M.I.M. Matthiessen. (2004). An introduction to functional grammar ( $3^{\text {rd }}$ ed.). London: Hodder Arnold.

Hay, J. (2000). Functions of humor in the conversations of men and women. Journal of Pragmatics. Vol 32 (6), 709-742.

Habib, H. (2008). Humor and disagreement: Identity construction and cross-cultural enrichment. Journal of Pragmatics. Vol 40 (6), 1117-1145.

Holmes, J. (2006). Sharing a laugh: Pragmatic aspects of humor and gender in the workplace. Journal of pragmatics, Vol 38 (1), 26-50.

Knud, S. L \& Le Van Hao. (2015). Tam Li Hoc Xuyen Van Hoa (Cross-cultural Psychology). Hanoi: VNU Press.

Kristeva, J. (1986). Word, dialogue and novel. In T. Moi (ed.), The Kristeva reader. Oxford: Blackwell.

Lakoff, G \& M. Johnson. (1980/2003). Metaphors we live by. Chicago and London: the University of Chicago Press.

Leech, G. N. (1983). Principles of pragmatics. London: Longman.

Lindblom, K. (2001). What exactly is cooperative in Grice's cooperative principle? A sophisticated rearticulation of the CP. RASK, International Journal of Language and Communication 14, 49-73.

Machin, D \& Mayr, A. (2012). How to do critical discourse analysis. LA, London, New Delhi, Singapore, Washington DC: Sage Publications.

Muhlhausler, Peter, Harre, Rom. (1990). Pronouns and people: the linguistic construction of social and personal identity. Oxford: Blackwell.

Tajfel, H. (1981). Human groups and social categories: Studies in social psychology. Cambridge: CUP.

Wooffitt, R. (2005). Conversation analysis and discourse analysis. London, Thousand Oaks, New Delhi: Sage Publications.

Jorgensen, M \& Phillips, R. (2002). Discourse analysis as theory and method. Los Angeles, London, New Delhi, Singapore, Washington: Sage Publications. 
Leary, M. R \& Tangney, J. P. (2003). Handbook of self and identity. New York: Guilford Press.

Markus, H. \& Kitayama, S. (1991). Culture and the self: Implications for cognition, emotion, and motivation. Psychological Review, Vol 98 (2), 224-253.

Mulder, M.P \& Nijholt, A. (2002). Humor research: state of the art. Center for Telematics and Information Technology, University of Twente. Retrieved November $11^{\text {th }}, 2015$, from http://wwwhome. cs.utwente.nl/ anijholt/artikelen/ctit24_2002.pdf.

Parker, Ian. (2002). Critical discursive psychology. Houndmills, Basingstoke, Hampshire, New York: Palgrave Macmillan.

Potter, J. (1996). Representing reality. London: Sage Publications.

Potter, J. \& Whetherell, M. (1987). Discourse and social psychology. London: Sage.

Raskin, V. (1979). Semantic mechanism of humor. Proceedings of the fifth annual meeting of the Berkeley Linguistics society, pp. 325-335. Retrieved November $11^{\text {th }}, 2015$, from http://journals. linguisticsociety.org/proceedings/index.php/ BLS/article/download/ 2164/1934.

Ricento, T. (2003). The discursive construction of Americanism. Discourse and Society 14(5), 611637. Retrieved January $5^{\text {th }}, 2016$ from http://das. sagepub.com/content/ 14/5/611.full.pdf.

Rorty, R. (1980). Philosophy and the mirror of nature. Cambridge: CUP.
Schopenhauer, A. (1883). The world as will and idea. Vol. 1. London: Routledge.

Stets, J. E and Burke, P. J. (2000). Identity and social identity theory. Social Psychology Quarterly 2000, Vol. 63 (3), 224-237. Retrieved September 9 ${ }^{\text {th }}, 2015$ from http://wat2146.ucr.edu/papers/00a.pdf.

Stokoe, E \& Benwell, B. (2006). Discourse and identity. Edinburgh: Edinburgh University Press.

Them, T, N. (2016). Hệ giá trị Việt Nam tù truyền thống đến hiện đại và con đường tới turong lai (Vietnamese values system: past, present and future). Ho Chi Minh: Nxb Văn hóa và Văn Nghệ - Culture and Literature Publisher.

Triandis, H. C. Individualism \& collectivism. (1995). Boulder \& Oxford: Westview Press.

Van Dijk, T. A. (2000). Discourse, ideology and context. Folia Linguistica 35(1-2), 11-40. Retrieved January $5^{\text {th }}, 2016$ from https://www.degruyter. com/downloadpdf/j/ flin.2001.35.issue-1-2/ flin.2001.35.1-2.11/flin.2001.35.1-2.11.xml

Wodak, R.\& Meyer, M. (2009). Methods of discourse analysis. Los Angeles, London, New Delhi, Singapore, Washington: Sage Publications.

Transcript of Mary's speech at the Dinner. Retrieved December $12^{\text {th }}, \quad 2015$, from http://time. com/4539979/read-transcript-hillary-Maryspeech-al-smith-dinner/.

\title{
KIẾN TẠO "IDENTITY" QUA HÀI HƯỚC NGÔN TÙ
}

\author{
Nguyễn Hòa \\ Truờng Đại học Ngoại ngũu, ĐHQGHN, Phạm Văn Đồng, Cầu Giấy, Hà Nội, Việt Nam
}

Tóm tắt: Bài viết trình bày nghiên cứu vai trò của tính hài hước trong ngôn ngữ trong việc kiến tạo và hiểu hình ảnh nhân vật (identity) trong một hoàn cảnh xã hội chính trị nhất định từ góc độ phân tích diễn ngôn phê phán trên nền tảng của lí luận kiến tạo xã hội (social constructionism). Tác giả không sử dụng phương thức phân tích ngôn ngữ truyền thống như Fairclough đề nghị, mà đã kết hợp phương pháp của CDA với dụng học của Grice trong quá trình phân tích để chỉ ra các chiến lược diễn ngôn được người nói vận dụng.

Tù khóa: căn tính, hình ảnh, hài hước, kiến tạo, diễn ngôn, tính liên văn bản, liên diễn ngôn 